\title{
Strategi Pengembangan Kapasitas Kelembagaan Dalam Rangka Optimalisasi Pembelajaran Masyarakat Berbasis IT Melalui Gerakan Klaten Go On Line
}

\section{Institutional Capacity Development Strategy to Optimizing Community Learning Through Klaten Movement Go On Line}

\author{
Wahyu Nurharjadmo, Priyanto Susiloadi \\ Program Studi Ilmu Administrasi Negara Fakultas Ilmu Sosial dan Politik \\ Universitas Sebelas Maret \\ wahyunurharjadmo@gmail.com
}

\begin{abstract}
Abstrak
Program Klaten Go On line sudah lebih dari dua tahun digulirkan dan diimplementasikan. Mengingat program ini menyasar pada seluruh masyarakat maka sangat dimungkinkan program ini tidak mulus dalam pengimplementasiannya. Berbagai hambatan mungkin dapat muncul. Untuk itu perlu dilihat strategi yang sudah dilaksanakan selama ini dan kemungkinan hambatan yang muncul Dengan mengetahui kualitas implementasi dan berbagai hambatan yang muncul maka selanjutnya dapat dirumuskan model strategi pengembangan kapasitas kelembagaan dalam rangka optimalisasi program pembelajaran masyarakat berbasis IT melalui program Klaten Go On line, sehingga upaya mewujudkan masyarakat digital bisa terwujud yang pada akhirnya bisa membantu mewujudkan keberhasilan pelaksanaan kegiatan pemerintahan dan pembangunan.
\end{abstract}

Kata kunci : strategi, kapasitas kelembagaan, Tehnologi informasi

\begin{abstract}
The Klaten Go On line program has been rolled out and implemented for more than two years. Considering this program is targeting the entire community, it is very possible that this program is not smooth in its implementation. Various obstacles may arise. Therefore, it is necessary to see the strategies that have been implemented so far and the possible obstacles that arise. By knowing the quality of implementation and the various obstacles that arise, then a strategy model for institutional capacity building can be formulated in order to optimize the IT-based community learning program through the Klaten Go Online program. realizing a digital society can be realized, which in turn can help realize the successful implementation of government and development activities.
\end{abstract}

Keywords: strategy, institutional capacity, information technology

\section{A. Pendahuluan}

Indonesia, sebagai negara sedang berkembang, dalam hal penggunaan IT khususnya di bidang pemerintahan, masih menduduki peringkat ke 33 dari 55 negara yang dipantau pelaksanaan Egovnya ( hasil pemantauan Waseda University tahun 2013). Sementara 
tuntutan perkembangan menyebabkan keberadaan internet dibidang yang lain seperti perdagangan, politik, pendidikan, kepegawaian kesehatan dan sebagainya merupakan sesuatu yang sifatnya mutlak. The internet is global phenomenon, but the way in which national governments respond to it varies with the political, social and economic context of a country (Rose, 2005).

Inovasi Kebijakan percepatan pemasyarakatan tehnologi informasi, dan berbagai program pemanfaatan IT di beberapa pemerintah daerah dilakukan dalam bentuk yang berbeda-beda. Kabupaten Klaten merupakan salah satu kabupaten yang merespon positif upaya untuk memasyarakatkan dan memanfaatkan IT dalam pelaksanaan pemerintahan dan pembangunannya. Pemerintah Kabupaten Klaten mencanangkan gerakan Klaten Go on line, yang dicanangkan bertepatan dengan hari jadi kabupaten Klaten ke 209 tanggal 29 juli 2013.

Klaten go on line merupakan konsep yang ingin mewujudkan Klaten sebagai sebuah wilayah yang memiliki koneksi terintegrasi dalam berbagai bidang sehingga memberikan dampak praktis dan efisien dalam mengelola sistem informasi wilayah. Klaten go on line juga merupakan sebuah spirit untuk membangun Klaten menuju masyarakat yang siap menerima perkembangan tehnologi informasi sehingga tercipta masyarakat yang mampu mengoptimalkan penggunaan internet dan komputer di berbagai bidang.
Digitalisasi daerah melalui program Klaten Go online diharapkan bisa meningkatkan pergerakan perekonomian lokal yang pada akhirnya akan bermuara pada kesejahteraan masyarakat. disamping mengefisienkan pelayanan pada publik. Menurut Kabag Humas Setda Kabupaten Klaten, dalam tahap awalnya Klaten go online diimplementasikan dalam beberapa hal yaitu :

1. Penyediaan layanan internet untuk masyarakat Klaten melalui pemasangan Indonesian Wifi, termasuk internet wifi untuk sekolah, kampus dan lembaga pendidikan.

2. Pengelolaan Broadband Learning Centre (BLC) sebagai wahana peningkatan pengetahuan dan keahlian dari berbagai unsur masyarakat mulai dari Pegawai, ABRI, pedagang, pelaku usaha dan berbagai komponen masyarakat lainnya.

3. Pembuatan master plann Klaten di bidang IT

4. Pengembangan Kampung IT dan UMKM berbasis IT

Hasil peneliitan yang dilakukan sebelumnya oleh Nurharjadmo dkk (2013) tentang evaluasi pelaksanaan satu dekade otonomi daerah menunjukkan bahwa Klaten Go online merupakan salah satu hasil inovasi kebijakan yang diambil pemkab Klaten yang pelaksanaan programnya masih belum mempunyai arah dan strategi yang jelas. Program ini juga belum didukung secara menyeluruh baik dari sisi penganggaran maupun kesiapan sumber daya manusia dan komitmen yang sungguh-sungguh dari pihak Pemerintah 
Kabupaten Klaten. Belum tersedianya regulasi yang pasti telah menyebabkan program ini berjalan seadanya, sementara masyarakat sangat berharap akan keberhasilan program ini.

Untuk itu guna lebih mengoptimalisasi dalam pelaksanaan program Klaten Go online tersebut maka dituntut kesiapan baik berkaitan dengan supra maupun infra struktur, anggaran dan juga kesiapan sumber daya manusianya. Dengan kata lain diperlukan strategi yang tepat terutama dalam pengembangan kapasitas kelembagaannya. Hal ini disebabkan karena salah satu indikator keberhasilan implementasi adalah tersedianya dukungan kelembagaan yang memadai (Meter dan Horn, 1988).

Dengan demikian maka permasalahan yang akan dikaji dirumuskan sebagai berikut :

1. Bagaimanakah strategi yang diterapkan dalam mengimplementasikan program Klaten Go Online di Kabupaten Klaten?

2. Apa saja hambatan-hambatan yang muncul dalam Implementasi Program Klaten Go on line di Kabupaten Klaten ?

3. Bagaimana strategi pengembangan kapasitas kelembagaan dalam rangka optimalisasi program Klaten Go online di Kabupaten Klaten ?

Dengan demikian maka pada bagian akhir kajian ini dapat disusun model Strategi pengembangan kapasitas kelembagaan dalam rangka optimalisasi pelaksanaan pembelajaran masyarakat berbasis IT melalui program Klaten Go online guna meraih tujuan yang diharapakan yaitu digitalisasi masyarakat.

\section{B. Tinjauan Pustaka}

a. Pengembangan

kapasitas kelembagaan

Pengembangan kapasitas pada dasarnya suatu proses yang dapat meningkatkan kemampuan sesorang, suatu organisasi atau suatu sistem untuk mencapai tujuan yang dicita-citakan (Brown, 2001:25). Morison menyatakan bahwa capacity building adalah suatu proses untuk melakukan sesuatu atau serangkaian gerakan perubahan multi level di dalam individu, kelompok-kelompok, organisasiorganisasi dan sistem-sistem dalam rangka untuk memperkuat kemampuan penyesuaian individu dan organisasi sehingga dapat tanggap terghadap perubahan lingkungan yang ada (Morison, 2001:42). Secara lebih spesifik pengembangan kapasitas kelembagaan yaitu pengembangan kapasitas tradisional mengenai permasalahan sumber daya manusia, proses dan struktur organisasi (Milen, 2004:21).

Dalam konsep yang dikembangkan oleh World Bank, capacity building, menekankan pada :

1. Pengembangan sumberdaya manusia: training, recruitment, dan pemutusan pegawai profesional, managerial dan tehnis

2. Keorganisasian yaitu pengaturan struktur, proses, sumber daya dan gaya manajemen

3. Jaringan kerja (network) berupa koordinasi, aktivitas organisasi, fungsi network, serta interaksi formal dan informal 
4. Lingkungan organisasi yaitu aturan (rule) dan undang-undang (legislasi) yang mengatur pelayanan publik, tanggung jawab dan kekuasaan antar lembaga, kebijakan yang menjadi hambatan bagi development tasks serta dukungan keuangan dan anggaran

5. Lingkungan kegiatan lebih luas lainnya meliputi faktor politik, ekonomi dan situasi yang mempengaruhi kinerja

Sementara itu UNDP memfokuskan Capacity building pada tiga dimensi :

1. Tenaga kerja (dimensi human resources) :kuliatas SDM

2. Modal (dimensi fisik) menyangkut sarana dan prasarana, peralatan, gedung dsb

3. Teknologi yaitu organisasi dan gaya manajemen, fungsi perencanaan, penentuan kebijakan, pengendalian dan evaluasi, komunikasi serta sistem informasi manajemen

Untuk melakukan pengembangan kapasistas dilakukan dalam beberapa tingkatan, diantaranya adalah ( Soeprapto, 2010) :

1. Tingkatan sistem : kerangka kerja yang berhubungan dengan aturan dan kebijakan

2. Tingkatan institusional : struktur organisasi, proses pengambilan keputusan, mekanisme kerja, pengaturan sarana dan prasarana, hubungan dan jaringan organisasi

3. Tingkatan individual : ketrampilan, pengetahuan, tingkah laku, pengelompokan pekerjaan dsb
Berbagai cara pengembangan kapasitas dapat dilakukan, diantaranya adalah :

1. Dalam tingkatan individual : pendidikan, pengajaran, pelatihan dsb

2. Dalam tingkatan kelembagaan : pengembangan aturan main organisasi, sistem kepemimpinan, sistem manajemen, pengembangan SDM dan jejaring organisasi

3. Dalam tingkatan sistem : pengembangan kebijakan atau aturan

Dalam Peraturan Pemerintah no 6 tahun 2008 tentang Pedoman Evaluasi Penyelenggaraan Pemerintahan, pengembangan kapasitas dapat berupa kegiatan fasilitasi di bidang kerangka kebijakan, kelembagaan dan sumberdaya manusia. Sementara itu berdasarkan Peraturan Pemerintah no 59 tahun 2012 tentang Kerangka Nasional Pengembangan Kapasitas pemerintahan daerah, dalam pasal 6 dinyatakan bahwa ruang lingkup pengembangan kapasitas pemerintahan daerah adalah :

1. Pengembangan kapasitas kelembagaan, meliputi :

a. Peningkatan kapasitas struktur organisasi yang efektif dan efisien, rasional dan proporsional

b. Peningkatan kapasitas tata laksana penyelenggaraan tupoksi

c. Pelembagaan budaya kerja organisasi yng produktif

d. Peningkatan kapasitas anggaran

e. Peningkatan kapasitas sarana dan prasarana

f. Penetapan SOP dalam penyelenggaraan pemerintahan 
2. Pengembangan kapasitas kelembagaan dilakukan melalui :

a. Penataan struktur organisasi yang tepat, melalui evaluasi dan analisis departementasi dan spesialisasi unit-unit kerja

b. Pembenahan mekanisme kerja dan metode serta hubungan kerja antar unit kerja dan antar unit organisais pemerintahan daerah

c. Perumusan nilai-luhur sebagai budaya organisasidan penanaman budaya organisasi

d. Penguatan dan pemantapan metode pengalokasian anggaran sesuai visi, misi dan sasaran

e. Penyediaan sarana dan prasarana yang sesuai standar

f. Penyediaan SOP (prosedur kerja) dan penetapan metode kerja modern berbasis ilmu pengetahuan

\section{b. Implementasi Kebijakan dan Faktor yang Mempengaruhi}

Menurut Darwin (!995: 1), implementasi kebijakan adalah" Serangkaian kegiatan yang dibuat untuk melaksanakan semua keputusan yang diambil". Presman dan Wildavsky seperti dikutip oleh Solihin Abdul Wahab (2005:60) mendefinisikan implementasi kebijakan, sebagai "to carry out, accomplish, fulfill, produce, complete”. Sedangkan menurut Van Horn dan Van Meter (1975:447) implementasi kebijakan diartikan sebagai "Those action by public an private individual (or groups) that are directed at the achiefment of objectives set fort in prior policy decisions.
Proses implementasi bukanlah proses mekanis di mana setiap aktor secara otomatis melakukan apa saja yang seharusnya dilakukan sesuai dengan skenario pembuat kebijakan, tetapi merupakan proses yang acapkali rumit, diwarnai perbenturan kepentingan antar aktor yang terlibat baik sebagai administrator, petugas lapangan, atau kelompok sasaran. Selama proses implementasi, beragam interprestasi atas tujuan, target dan strategi implementasi dapat berkembang..

Implementasi kebijakan hakekatnya merupakan cara sebuah kebijakan untuk dapat mewujudkan tujuannya. Hal itu tentunya akan berhubungan dengan resources yang dimiliki serta aturan pelaksanaan yang ada. Dalam rangka implementasi kebijakan, berbagai faktor bisa mempengaruhinya. Faktor itu akan bersifat positif (yang berfungsi sebagai faktor pendorong jika ada dan bekerja baik), namun juga bersifat negatif (faktor penghambat jika tidak ditemukan atau kurang bekerja dengan baik). Salah satu faktor yang mempengaruhi proses implementasi sebuah kebijakan adalah adanya dukungan dan komitmen dari badan pelaksana dan sikap para pelaksananya (Meter \& Horn, 1975, Sabatier,1981)

Menurut Sabatier variabel yang paling berpengaruh terhadap output kebijakan adalah kesepakatan para pejabat badan pelaksana terhadap upaya mewujudkan tujuan kebijakan tersebut. dalam hal ini sedikitnya terdiri atas 2 komponen yaitu, pertama arah dan rangking tujuan kebijakan tersebut dalam skala prioritas pejabat tersebut, dan kedua kemampuan 
pejabat tersebut dalam mewujudkan prioritas tersebut (Abdulwahab, 2005). Untuk itu agar dapat mengimplementasikan sebuah kebijakan dengan baik diperlukan pengembangan kapasitas baik dari sisi kelembagaan maupun kemampuan individu pelaksana guna mengantisipasi dan menjawab perubahan yang diharapkan. Menurut Bryant and White (1982), pembangunan kapasitas menekankan pada apa yang harus dilakukan untuk meningkatkan kemampuan serta enerji yang diperlukan untuk mewujudkan harapannya.

Edward (1980) mengemukakan adanya 4 variabel yang berpengaruh terhadap efektivitas implementasi kebijakan. Hal ini didasari pada dua buah pertanyaan: Pra kondisi-prakondisi apa yang diperlukan agar implementasi kebijakan berhasil?; Hambatan-hambatan utama apa yang mengakibatkan suatu implementasi gagal? Untuk menjawab pertanyaan ini Edward mengemukakan adanya 4 variabel yang mempengaruhi keberhasilan implementasi.

Variabel pertama adalah komunikasi. Ini mencakup: transmisi, konsistensi dan kejelasan (Winarno, 2002:126). Syarat agar implementasi kebijakan efektif adalah para pelaksana harus mengetahui apa yang harus mereka lakukan. Keputusan-keputusan kebijakan harus disertai dengan petunjuk-petunjuk yang jelas sehingga pelaksana tidak mengalami kebingungan. Selain itu,perintah pelaksanaan harus konsisten dan jelas. Variabel kedua adalah ketersediaan sumber-sumber. Ini mencakup jumlah staff yang memadai dan berkualitas, dana serta fasilitas yang diperlukan untuk menterjemahkan kebijakan-kebijakan yang telah dirumuskan agar dapat terealisir. Tanpa adanya sumber-sumber maka kebijakan-kebijakan hanya akan menjadi rencana saja dan tidak pernah ada realisasi.

Variabel ketiga adalah disposisi-disposisi pelaksana. Para pelaksana harus bersikap baik dan memberikan dukungan terhadap kebijakan tersebut. Sebaliknya, jika tingkah laku para pelaksana berbeda dengan para pembuat keputusan, maka proses pelaksanaan suatu kebijakan menjadi semakin sulit. Variabel keempat adalah struktur birokrasi. Menurut Edward, birokrasi merupakan salah satu badan yang paling sering bahkan secara keseluruhan menjadi pelaksana kebijakan. Meskipun pelaksana kebijakan harus mengetahui apa yang dilakukan dan berkeinginan kuat serta sumber-sumber untuk melaksanakannya, tetapi dalam pelaksanaannya mereka sering dihambat oleh struktur -struktur organisasi yang kompleks.

Menurut Edward, ada dua hal penting yang berhubungan dengan implementasi kebijakan dalam kehidupan birokrasi, yaitu keberadaan Standar Operasional Prosedur (SOP) dan fragmentasi. SOP yang berkembang sebagai tanggapan internal terhadap waktu yang terbatas dan sumbersumber dari pelaksana serta keinginan untuk keseragaman dalam bekerjanya organisasi yang kompleks. Fragmentasi ini terutama berasal $t$ dari tekanan-tekanan di luar unit organisasi seperti legislatif, kelompok kepentingan, pejabat eksekutif, konstitusi negara, dan sifat kebijakan yang mempengaruhi organisasi birokrasibirokrasi pemerintah. 
Nurharjadmo dkk. (2013) dalam penelitian evaluasi satu dekade pelaksanaan otonomi daerah di Kabupaten Klaten dan Kota Surakarta, menemukan bahwa program Klaten Go online merupakan salah satu kebijakan inovatif yang dikembangkan untuk memasyarakatkan penggunaan IT pada seluruh jajaran masyarakat, masih belum berjalan optimal dan masih bersifat sektoral dan cenderung parsial dan kurang terikoordinasi dengan baik sehingga belum sesuai harapan. Masih banyak yang harus dilakukan untuk mengoptimalkan khususnya yang berkaitan dengan penguatan kapasitas kelembagaannya.

Beberapa hasil penelitian yang berkiatan dengan perlunya penguatan kelembagaan dilakukan oleh Wahyono (2011) yaitu mengenai penguatan kelembagaan dalam menemukan keberhasilan program desa informasi, Nurnaningsih dan Rusli (2010) tentang Penguatan kelembagaan dalam penerimaaan PAD, Razak (2013) (penguatan kelembagaan Dewan Perwakilan daerah), Shuaib (2008) meneliti tentang Penguatan kelembagaan dalam administrasi hukum islam di Malaysia. Sedangkan Retnasari dkk meneliti tentang penguatan kapasitas kelembagaan di BKD kabupaten Jombang. Hasil-hasil peneliitan tersebut secara umum menyatakan bahwa pengembangan kapasitas kelembagaan sangat diperlukan dalam mendukung pelaksnaan program maupun kinerja sebuah lembaga.

Penelitian ini merupakan penelitian lanjutan yang mendasarkan dari hasil penelitian sebelumnya tentang dinamika otonomi daerah yang dilakukan oleh peneliti, yang mengevaluasi tentang pelaksanaan otonomi daerah di Kabupaten
Klaten dan Kota Surakarta. Dengan demikian melalui penelitian ini akan lebih dapat diketahui apa dan bagaimana implementasi program tersebut, sehingga bisa lebih memberikan hasil yang kongkrit bagaimana mewujudkan masyarakat yang menguasai IT melalui Klaten Go on line di kabupaten Klaten, sehingga upaya mewujudkan masyarakat yang cerdas dan sejahtera berbasis pada penguasaan IT bisa terlaksana.

\section{Metode Penelitian}

Penelitian ini merupakan penelitian deskriptif kualitatif, yaitu mendeskripsikan strategi pelaksanaan pembelajaran masyarakat berbasis IT melalui program Klaten Go online dan hambatan yang muncul untuk kemudian mengembangkan model penguatan kelembagaan dalam rangka mengoptimalisasi pelaksanaan program Klaten go online. Lokasi Penelitian ini adalah Kabupaten Klaten. Unit analisis penelitian adalah pihak yang terlibat secara langsung dalam mengimplementasikan program Klaten Go on line. Data primer berasal dari informan yang ditetapkan secara purposive. Informan terdiri atas beberapa pejabat di Pemerintah Kabupaten Klaten, seperti Bagian Humas, Bappeda, PT Telkom Indonesia Tbk Cabang Klaten, KPLI (Kelompok Pengguna Linux Indonesia) Kabupaten Klaten, dan beberapa stakeholder yang terlibat dalam implementasi program Klaten Go Online, seperti kelompok PNS, ABRI, UMKM, siswa sekolah dan sebagainya. Sedangkan data sekunder berupa dokumen atau arsip, catatan berkaitan dengan pelaksanaan Klaten Go Online, Nota kesepahaman antara Pemkab dan PT Telkom dan KPLI, 
Kegiatan di BLC catatan notulen hasil rapat dan sebagainya.

Data pada penelitian ini dikumpulkan melalui observasi, studi dokumentasi, focus group discussion, wawancara mendalam. Analisis data dalam penelitian ini dilakukan melalui analisis deskriptif kualitatif. dengan menggunakan model analisis interaktif dari Miles danHuberman (HB Sutopo,2002). Guna menjamin validitas data, digunakan 2 jenis triangulasi, yaitu triangulasi data dan triangulasi sumber. Dalam penelitian ini peneliti melakukan "cross check" terhadap data yang dikumpulkan dari sumber yang berbeda, yaitu informan, catatan lapangan dan dokumen.

\section{Hasil Penelitian dan Pembahsan \\ a. Strategi yang diterapkan dalam mengimplementasikan Klateh Go On line}

Program Klaten Go Online merupakan suatu program yang ingin menjadikan wilayah Kabupaten Klaten memiliki koneksi terintegrasi dalam berbagai bidang sehingga memberikan dampak praktis dan efisiensi dalam pengelolaan sistem informasi wilayah. Unutk mewujudkan hal itu maka disusunlah Nota Kesepahaman antara pihak Pemkab Klaten, PT Telkom Tbk Klaten dan Kelompok Pengguna Linux Indonesia (KPLI).

Dalam kesepakatan tersebut ditentukan bahwa pelaksanaan program Klaten Go on line akan dilaksanakan oleh Broadband Learning Center (BLC) Telkom sebagai ujung tombaknya. Program Klaten Go on line yang berupa pembelajaran masyarakat diwujudkan melalui pemberian pelatihan internet. Untuk itu maka BLC Telkom kemudian oleh pemkab Klaten dirombak dan difasilitasi yaitu diberi tempat dan sarana komputer yang lebih besar, yang didukung dengan akses internet broadband dari Telkom. Sedangkan instruktur pelatihan dari Kelompok Pengguna Linux Indonesia Klaten.

Ada tiga point penting dalam nota kesepahaman tersebut yaitu :

1. Implementasi Indonesia Wifi, yaitu layanan internet Wifi untuk masyarakat Klaten, termasuk program indischool, yaitu internet Wifi untuk sekolah, kampus dan lembaga Pendidikan di kabupaten Klaten

2. Pengelolaan BLC sebagai wahana meningkatkan pengetahuan dan keahlian para pegawai negeri sipil dan masyarakat umum di bidang IT

3. Pembuatan master plann Kabupaten Klaten di bidang IT untuk menuju Klaten Go On line

Sebagai institusi yang ditunjuk sebagai ujung tombak pelaksanaan program Klaten Go Onlie, maka BLC memiliki visi yaitu “ membentuk masyarakat peduli terhadap Tehnologi Informasi dan komunikasi sehingga dapat diterapkan sesuai bidangnya". Sedangkan misinya adalah

1. Memberikan pelatihan Tehnologi Informasi dan komunikasi pada masyarakat secara gratis.

2. Mewujudkan masyarakat yang sadar menggunakan internet secara sehat dan aman

3. Pemberdayaan masyarakat melalui IT/ internet 
Dalam rangka melaksanakan visi misinya tersebut BLC Klaten menawarkan 3 kelas pelatihan sesuai tingkatan kebutuhan masyarakat, yaitu : Kelas basic (dasar) berisi open source, web development dan internet network pengenalan internet sehat, browsing dan searching serta email, Kelas Intermediate (lanjutan) berisi tentang internet sehat, social media dan blogging dan Kelas advantege (Mahir) nmengajarkan

Dalam melaksanakan kegiatannya BLC memberikan layanan pelatihan selama 24 jam, sesuai dengan permintaan dari warga masyarakat. Adapun stakeholder yang sudah berpartisipasi dalam penggunaan jasa BLC antara lain :

1. Pihak PT Telkom TBk

2. Pegawai di Pemkab Klaten

3. KPLI

4. Jajaran institusi pendidikan di seluruh kabupaten Klaten

5. Jajaran kepolisisan resort Klaten

6. jajran TNI di Kabupaten Klaten

7. Komunitas UMKM

Beberapa pelatihan juga telah dilakukan oleh BLC dijelaskan dalam tabel 1.

Tabel 4

Jenis pelatihan dan peserta pelatihan yang pernah dilakukan oleh BLC dalam mewujudkan Program Klaten GO On Line

\begin{tabular}{|c|c|c|}
\hline No & Jenis dan materi Pelatihan & Peserta \\
\hline 1. & $\begin{array}{l}\text { Pelatihan Desain Sistem Aplikasi E government } \\
\text { Berbasis Free \& Open Source Saftware (FOSS) }\end{array}$ & SKPD \\
\hline 2. & Pelatihan intrenet dasar & $\begin{array}{l}\text { Kodim dan } \\
\text { beberapa SKPD }\end{array}$ \\
\hline 3. & Pelatihan internet dasar & $\begin{array}{l}\text { Lurah pasar se } \\
\text { kab klaten }\end{array}$ \\
\hline 4. & Pelatihan Web server & Bank Klaten \\
\hline 5. & Pelatihan Internet berbasis aplikasi E government & $\begin{array}{l}\text { Tenaga IT tiap- } \\
\text { tiap SKPD }\end{array}$ \\
\hline 6. & Pelatihan internet dasar abgai perangkat Desa & Perangkat desa \\
\hline 7. & Pelatihan komputer dan intrenet ibu-ibu UPTD & Ibu-ibu UPTD \\
\hline 8. & $\begin{array}{l}\text { Pelatihan SIRUP (Sistem Informasi Rencana Umum } \\
\text { Pengadaan }\end{array}$ & Staff kecamatan \\
\hline 9. & $\begin{array}{l}\text { Pelatihan pembuatan aplikasi Sosisliasai dan } \\
\text { pengelolaan Unit layanan Informasi dan Pengadaan } \\
\text { (ULIP) }\end{array}$ & SKPD \\
\hline 10 & Pelatiahan internet sehat untuk sekolah & Guru \\
\hline 11 & $\begin{array}{l}\text { Pelatihan internet untuk siswa mulai dari PAUD } \\
\text { sampai SLTA }\end{array}$ & Siswa \\
\hline 12 & $\begin{array}{l}\text { Workshop pembuatan portal sistem informasi } \\
\text { manajemen pendidikan }\end{array}$ & SMK Muh \\
\hline 13 & Pelatihan internet bagi ibu-ibu pembataik & Pembatik Bayat \\
\hline 14 & Pelatihan G mail dan Blog pada kelompok masyarakat & Desa \\
\hline
\end{tabular}

sumber : BLC Telkom- Klaten 
Dari tabel 1 nampak bahwa berbagai bentuk pelatihan telah dilakukan oleh pelaksana dengan peserta yang juga beragam asal dan tujuannya. Jika dilihat dari segi jenis atau jumlah pelatihan yang telah dilakukan, menunjukkan frekwensi atau jumlah yang cukup besar. Namun dalam kenyataannya sifatnya masih masif, kurang terintegratif dan terencana dengan baik. Proses pembelajaran masih terbatas pada kelompok masyarakat tertentu dari wilayah tertentu yang membutuhkannya, sehingga arahnya menjadi tidak jelas. Misal hanya dari kelompok masyarakat

desa tertentu saja dan tidak tersistematis untuk semua desa atau kecamatan. Demikian juga yang untuk pegawai, hanya terbatas beberapa SKPD saja, yaitu yang telah mengajukan permohonan untuk diberikan pelatihan, belum ada upaya memberikan jadwal yang lebih tegas untuk seluruh SKPD. Menurut pengelola BLC hal itu dilakukan mengingat keterbatasan dana dan tempat yang dimiliki, serta padatnya waktu pelaksanaan pelatihan. Inisiatif itu diharapkan memang datang dari warga masyarakat. Hal ini berdampak kurang optimalnya pelaksanaan Klaten Go On line.

Berdasarkan hasil wawancara yang dilakukan dengan Kepala Bagian Humas Kabupaten Klaten sebagai institusi yang bertanggung jawab dalam pelaksanaan program ini nampaknya program pembelajaran masyarakat yang telah dilakukan oleh BLC Telkom belum mampu menjawab apa yang menjadi keinginan pemerintah kabupaten Klaten. Koordinasi dengan pihak Pemkab jarang sekali dilakukan baik dalam hal recruitment peserta materi pelatihan maupun waktu kegiatan.. Akibatnya pelaksanaan program pembelajaran masyarakat belum memiliki strategi yang jelas, kurang tersusun secara sistematis dan terencana, baik peserta maupun kurikulum atau materinya, sehingga manfaatnya masih kurang dirasakan. Hal ini mengingat materi yang diberikan masih hal-hal yang bersifat umum dan kurang sesuai dengan kebutuhan kelompok peserta pelatihan.

Pihak pelaksana yaitu dari BLC membenarkan hal itu dan menyatakan bahwa memang untuk pengetahuan yang sifatnya khusus tidak diberikan oleh pihak BLC, karena berbagai keterbatasan baik keterbatasan dana maupun tenaga pengajarnya, karena hal itu menuntut kurikulum yang lebih spesifik dan berubah-ubah sesuai kebutuhannya. Dengan berbagai keterbatasan tersebut pihak pelaksana lebih memilih memberikan pengetahuan yang sifatnya umum, agar para peserta lebih bisa berinovasi dan mempelajari secara lebih mendalam secara mandiri sesuai kebutuhan yang diinginkannya.

Pelaksana hanya memberi kesempatan kepada siapapun warga masyarakat yang ingin belajar IT dengan memberikan bekal pemahaman pengetahuan IT mulai dari tingkat yang paling mendasar sampai advanced, sementara pihak pengguna lebih menginginkan pengetahuan yang praktis yang langsung berhubungan dengan tugas atau kegiatan mereka sehari-hari. Itulah sebabnya maka yang memanfaatkan jasa BLC justru banyak dari warga diluar Klaten, karena proses rekruitment mereka dilakukan secara bebas, on line dan tidak terjadwal secara sistematis. Mereka yang 
banyak mengakses informasi melalui internetlah yang tahu tentang hal tersebut, sehingga mereka ikut ambil bagian, sementara masyarakat yang semestinya diberikan pembelajaran, khususnya bagi kalangan umum seperti UMKM, atau kelompok masyarakat lainnya masih belum banyak memanfaatkan program ini, karena belum banyak berinteraksi dengan internet, sehingga cenderung kurang terwakili. Ini bisa dilihat dari pesertanya yang sebagian besar adalah para siswa-siswa sekolah.

Pihak BLC juga tidak melakukan sosialisasi secara langsung dengan tatap muka atau media lain untuk menarik minat masyarakat. Disamping alasan ketiadaan dana yang diberikan oleh Pemerintah, mereka berasumsi bahwa kelompok masyarakat yang butuh pengetahuan tentang IT yang seharusnya datang dan belajar di BLC. Dalam anggapan mereka BLC bukan seperti sekolah formal yang harus mensosialisasikan pada masyarakat agar memperoleh siswa, tetapi masyarakat yang menginginkan akan diberikan pengetahuan tentang IT dengan gratis dan pelayanan yang sebaik-baiknya. Namun fakta yang terjadi adalah bahwa masyarakat cenderung belum terbiasa proaktif dalam merespon berbagai kebijakan pemerintah.

Dengan kata lain perbedaan dalam cara pandang telah menyebabkan program kurang berjalan secara maksimal. Belum ada sinergi diantara para stakeholder kebijakan. Pihak pengelola sekaligus pelaksana kurang memiliki strategi yang jelas untuk mengoptimalkan proses penyebarluasan informasi pada masyarakat, sehingga masyarakat yang mengakses masih sangat terbatas. Belum adanya payung hukum yang lebih tegas seperti
Perda atau Perbup tentang program ini menjadikan dukungan dana menjadi tidak maksimal. Sampai sat ini baru nota kesepahaman diantara pihak Pemkab, PT Telkom dan pihak KPLI, yang menjadi landasan hukum pelaksanaan program Klaten Go On line.

Ketiadaan dana dari APBD mengakibatkan pelaksana cenderung mencari biaya sendiri untuk mewujudkan program Klaten Go On. Strategi yang dilakukan masih terbatas pada upaya memberikan pelayanan dalam proses pembelajaran, namun belum menyasar pada upaya memaksimalkan keterlibataan masyarakat kabupaten Klaten dalam proses pembelajaran. Dengan kata lain strategi yang dilakukan belum mengarah pada upaya pencapaian visi dan misi serta tujuan program.

Dengan demikian dapat dikatakan bahwa proses implementasi program pembelajaran masyarakat berbasis IT melalui program Klaten Go On line belum berjalan maksimal dan masih banyak ditemukan hambatan-hambatan didalamnya. Ini menunjukkan bahwa strategi yang diterapkan dalam mengimplementasikan program belum bisa berjalan atau bahkan cenderung tidak ada. Pelaksana terkesan hanya melaksanakan sesuai dengan apa yang menjadi kemauannya tanpa ada arah dan tujuan yang jelas. Belum terumuskannya secara kongkrit apa yang menjadi target, sasaran maupun petunjuk pelaksanaan yang jelas untuk mendukung pelaksanaan program ini menjadi bukti bahwa pelaksnaan program berjalan kurang maksimal.

\section{b. Faktor-faktor penghambat}


Berdasarkan analisa terhadap proses implementasi program maka dapat diidentifikasi sejumlah hambatan, diantaranya adalah :

\section{Komunikasi}

Salah satu hal yang menyebabkan proses pelaksanaan program Klaten Go on line tidak bisa maksimal adalah kurangnya komunikasi yang dibangun antar stake holder, yaitu antara pihak Pemkab Klaten, dan PT Telkom dengan pihak pelaksana yaitu KPLI. Hal ini dikemukakan oleh Kepala Bagian Humas pemerintah Kabupaten Klaten Klaten yang menekankan kurangnya koordinasi antar stakekholder. Namun menurut pelaksana kondisi ini terjadi karena pihak Pemkab Klaten kurang serius dalam menggarap program ini.

Sementara itu pihak PT telkom TbK selaku penyedia jaringan juga merasakan hal yang sama. Dari sisi pelaksanaan mereka menganggap sudah berjalan hanya saja mengenai efektifitas dan kemanfaatannya masih dirasa kurang. Karena kurangnya komunikasi dan koordinasi justru pemanfaat layanan pembelajaran masyarakat yang ada di BLC bukan dari masyarakat Kabupaten Klaten, akan tetapi justru dari luar kabupaten Klaten, seperti dari Propinsi Jatim, Jabar atau bahkan dari luar jawa, seperi NTT, Papua, Medan dan sebagainya.

Hal ini menunjukkan adanya hambatan komunikasi antar pihak-pihak yang terlibat dalam kebijakan tersebut, khususnya antara pelaksana dan pihak Pemkab Klaten. Hambatan komunikasi menyebabkan tidak terjadinya sinergi antara pemkab dan pelaksana kebijakan, yang pada akhirnya menyebabkan pelaksanaan program menjadi tidak terarah tidak memliki strategi, target dan sasaran yang jelas.

\section{Sikap Pelaksana}

Dari hasil penelitian juga nampak adanya hambatan inkonsistensi dari para pelaksana. baik yang ditunjukkan oleh pihak KPLI dengan aktivitas BLC nya sebagai pelaksana maupun Pemkab Klaten dan PT Telkom. Secara teoritik komitmen dari pihak-pihak yang terlibat/ sikap pelaksana akan sangat mempengaruhi efektivitas pelaksanaan program. Para pelaksana yang dalam hal ini adalah KPLI melalui BLC dalam istilah Kepala Bagian Humas Pemkab Klaten dinilai masih cenderung seenaknya sendiri. Karena mereka berbasis dari LSM maka mereka bekerja dengan cara-cara yang tidak sinkron dengan tata cara kerja birokrasi. Mereka membuat perencanaan meliputi jadwal dan promosi sendiri tanpa melibatkan pihak pemkab dan telkom, menyusun kurikulum sendiri tanpa berkoordinasi dengan stakeholder yang lain dan sebagainya. Bahkan pihak pemkab menilai ada kecenderungan para pelaksana (dari KPLI) meninggalkan pihak pemkab. Namun menurut pihak KPLI sebagai pelaksana hal itu disebabkan karena kurangnya komitmen dari pemkab. Mereka berpendapat bahwa jika harus menunggu dari pemkab semua tidak bisa berjalan secara masksimal, cenderung sangat prosedural dan masih serba tidak jelas.

\section{Keterbatasan resources}

Keterbatasan resources juga menjadi kendala dalam pelaksanaan program Klaten Go on line. Dalam hal ini resources yang dimaksud berkaitan dengan keterbatasan sumber daya manusia, peralatan maupun dananya. Untuk SDM hampir semua tenaga pelatihan yang dilakukan oleh KPLI di 
BLC semuanya dari KPLI sendiri tidak melibatkan pegawai Pemkab. Jumlahnyanyapun sngat sedikit hanya sekitar 7 orang. Mereka adalah anggota KPLI yang kurang menguasai tehnik dan kurikulum yang dibutuhkan oleh masyarakat, meski secara tehnis mereka sangat menguasai keahlian komputer dan internet. Hal ini tentu berdampak pada kemanfaatan dari kegiatan ini. Hal itu dinyatakan oleh pihak Pemkab yang juga dibenarkan oleh pihak pelaksana sendiri.

Sementara untuk dana, meski sudah dua tahun berjalan masih belum ada dukungan dana yang pasti dari pemkab untuk membiayai pelaksanaan program Klaten $G o$ On line. Untuk kelancaran program saat ini semua biaya yang dibutuhkan ditanggung oleh pelaksana yaitu pengurus BLC sendiri. Bahkan para tenaga instruktur kepelatihanpun tidak menerima pembayaran. Mereka melakukannya secara sukarela, karena memang program pembelajaran ini dilakukan secara gratis.

Sementara untuk fasilitas ataupun peralatan, pihak Pemkab hanya memberikan bantuan untuk tempat kegiatan dan sebuah mobil untuk operasionalnya. Pihak PT Telkom memberikan bantuan peralatan, dan jaringan meski jumlahnya sangat terbatas. dan kurang memadai jika dibandingkan dengan kebutuhan untuk pelaksanaan program yang cukup besar. Di BLC baru tersedia sekitar dua puluh lima komputer, sehingga sangat dirasa kurang untuk dapat memenuhi kebutuhan masyarakat Kabupaten Klaten yang demikian besar. Akibatnya jadwal pelaksanaan pelatihan bagi masyarakat yang menghendaki bahkan berjalan 24 jam. Dalam kenyataannya memang aktivitas pelatihan juga banyak dilakukan pada waktu malam hari. hal ini tentu berpengaruh pada efektivitas dan efisiensinya.

\section{Struktur birokrasi}

Meski sudah dibentuk struktur organisasi untuk melaksanakan program namun tidak berjalannya struktur tersebut menyebabkan program tak bisa berjalan maksimal. Belum adanya SOP atau petunjuk pelaksanaan yang jelas menyebabkan program berjalan seolah-olah tanpa arah,target dan sasaran serta tujuan yang jelas.

Disamping itu belum ada sistem kelembagaan yang jelas dalam melaksanakan program sehingga ada kecendeurngan pihak pelaksana berjalan sendiri tanpa dukungan dari pihak Pemkab Klaten. Komitmen pemkab untuk mensukseskan program ini juga terlihat masih kurang masimal. Mereka hanya menyusun kesepahaman tetapi tidak segera menindaklanjuti dengan regulasi atau payung hukum yang jelas, sehingga terkesan membiarkan program berjalan tanpa ada payung hukum dan mekanisme serta sistem yang jelas, baik dalam hal implementasinya, pertanggungjawabannya maupun kemanfaatannya.

\section{c. Strategi Pengembangan Kapasitas kelembagaan}

Dengan memperhatikan fakta-fakta dalam proses implementasi tersebut maka dapat dirumuskan model strategi pengembangan kapasitas kelambagaan untuk mendukung optimalisasi pelaksanaan program pembelajaran masyarakat berbasis IT melalui program Klaten Go On line. Berdasarkan kajian teoritik dan dengan didukung dengan hasil uji coba atas model yang telah dirumuskan dalam pelaksanaan 
program Klaten Go on line, secara prinsip upaya pengembangan kapasitas kelembagaan perlu dilakukan paling tidak dalam dua tingkatan yaitu pada tingkatan sistem dan tingkatan kelembagaan.

Pada tingkatan sistem pihak stakeholder khususnya pemerintah Kabupaten Klaten perlu segera menyusun peraturan perundangan atau regulasi sebagai payung hukum untuk pelaksanaan kebijakan. Hal ini dilakukan guna memperjelas dan memberi kepastian langkah implementasi baik yang berkaitan dengan dukungan sumber daya manusia, peralatan maupun dana yang seharusnya digunakan. Adanya payung hukum yang diikuti dengan aturan pelaksanaan dan SOP menyebakan pelaksnaan kegiatan bisa diukur dan dinilai efektivitas dan efisiensinya. Sementara pada tingkatan kelembagaan, masih banyak yang harus dilakukan mulai dari penyempurnaan struktur organisasi, pengembangan manajemen pelaksanaan mulai dari perencanaan sampei dengan evaluasinya, sistem pembagian tugas dan kewenangan, pengalokasian dana hingga penyediaan SDM

Dengan mengacu pada kedua hal tersebut maka disusnlah model strategi pengembangan kapasitas kelembagaan dengan mendasarkan pada hambatan yang ditemukan. Agar pelaksanaan bisa optimal maka dalam model tersebut dicantumkan beberapa hal sebagai berikut :

1. Perumusan payung hukum sebagai landasan untuk mengimplementasikan program

2. Perlu dibangun kelembagaan yang jelas mulai pada keberadaan struktur sampai pada prosedur dan mekanisme kerja pelaksanaan program pembelajaran.

3. Pengembangan sistem yang integratif untuk melaksanakaan program mulai dari perencanaan, penganggaran, pelaksanaan, pengawasan program dan monitoring hingga evaluasi sehingga dapat dilakukan mekanisme check dan recheck atas optimalisasi keberhasilan pelaksanaan program

4. Penyiapan sumber daya manusia dan kurikulum, serta peningkatan fasilitas /peralatan guna mendukung pelaksanaan pelatihan yang jelas bagi setiap peserta kursus sesuia kebutuhannya.

Adapun model yang berhasil dirumuskan setelah diujicobakan digambarkan dalam bagan 1 .

\section{Bagan 1}

Model Strategi Pengembangan Kapasitas

Kelembagaan Dalam Rangka Optimalisasi

Pembelajaran Masyarakat Berbasis

Teknologi Informasi Mellaui Program

Klaten Go On Line

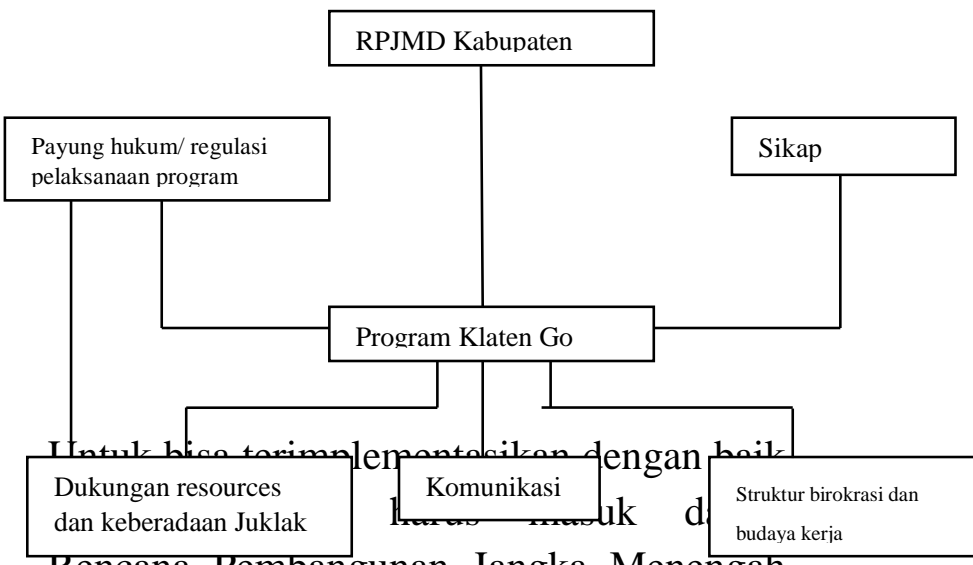

Kencana Pembangunan Jangka Menengah

Daerah (RPJMD). Untuk itu diperlukan suatu strategi yang tepat guna mengoptimalkan program Klaten Go On Line tersebut. Untuk itu ada beberepa komponen yang harus terpenuhi yaitu : 
1. Payung hukum/ regulasi pelaksanaan Program

payung hukum atau regulasi yang dimaksud dalam hal ini adalah Peraturan Daerah atau keputusan Bupati. Hal ini mengingat regulasi menjadi dasar dilaksanakannya sebuah kebijakan. Dengan regulasi yang jelas maka dukungan anggaran dan komitmen pemerintah menjadi jelas, sehingga akan memudahkan pelaksanaan kebijakan. Dengan disusunnya regulasi/ kebijakan ini maka akan menjadi jelas landasan yuridis bagi pelaksanaan program.

2. Dukungan resources dan keberadaan juklak maupun SOP

Implementasi program tidak akan bisa terlaksana tanpa dukungan resources yang memadai. Dalam hal ini berkaitan dengan sumber daya manusia, dana dan fasilitas. Untuk dana, diperlukan dukungan dana yang khusus untuk mengimplementasikan program. Dalam hal ini dengan adanya regulasi maka akan tersedia dana khusus yang bersumber dari APBD.

3. Sikap pelaksana

Keberhasilan pelaksanaan program tergantung pada kualitas dan sikap para pelaksana dalam memandang program tersebut. Perlu komitmen bagi pelaksana maupun pembuat kebijakan untuk mensukseskan program. Adanya komitman akan berdampak pada berbagai dukungan resources yang digunakan.

4. Komunikasi antar pelaksana

Keberhasilan pelaksanaan program hanya bisa terjadi jika ada komunikasi yang intensif diantara pihak-pihak yang terlibat dalam pelaksanaan dan perumusan kebijakan. Dengan adanya komunikasi yang intensif maka koordinasi pelaksanaan kegiatan bisa maksimal. Hal ini tentu alan berpengaruh pada efektivitas pemcapaian tujuan

5. Struktur birokrasi dan budaya kerja Keberhasilan implementasi kebijakan akan tergantung pada dukungan institusi yang terlibat maupun struktur organisasi pelaksananya. Disamping itu juga pada aspek budaya kerja para pelaksananya. Birokrasi yang baik tentunya akan mendukung setiap pelaksanaan kebijakan. Ini bisa terwujud dari kejalasan struktur tugas dan tanggung jawab para pelaksana maupun budaya kerjanya.

\section{E. Penutup}

Secara umum dapat disimpulkan bahwa setelah lebih dari dua tahun program Klaten Go On line diimplementasikan ternyata hasilnya masih kurang optimal. Belum nampak strategi implementasi yang jelas dalam mewujudkan Klaten Go on line tersebut. Kapsasitas lelembagaan yang mendukung program tersebut masih dirasa sangat kurang. Masih banyak ditemukan hambatan-hambatan dalam pengimplementasiannya mulai dari hambatan komunikasi, struktur birokrasi, sikap pelaksana hingga dukungan resources. Untuk itu maka guna lebih mengoptimalkan perlu dikembangkan strategi pengembangan kapasitas kelembagaan, paling tidak pada tingkatan sistem dan kelembagaannya. Mulai dari penyediaan payung hukum dan petunjuk pelaksanaannya hingga pada dukungan 
resources dan komitmen pada pelaksanaannya.

\section{Daftar Pustaka}

Kementerian Perencanaan Pembangunan Nasional/Badan

Perencanaan

Pembangunan

Nasional

(BAPPENAS), 2010. Lampiran

Peraturan Presiden RI Nomor 5

Tahun 2010 tentang: Rencana

Pembangunan jangka Menengah

Nasional (RPJMN) tahun 20102014

Peraturan Pemerintah no 6 tahun 2008 tentang Pedoman Evaluasi penyelenggaraan Pemerintahan

Peraturan Pemerintah no 59 tahun 2012tentang Kerangka Nasional pengembangan Kapasitas pemerintahan daerah

Peraturan Daerah Kabupaten Klaten nomor 5 tathun 2011 tentang Rencana Pembangunan Jangka menengah Daerah (RPJMD) Kabupaten Klaten tahun 2010-2015

Kabupaten Klaten Dalam Angka Tahun 2013, Bapeda Kabupaten Klaten, 2014

Abdulwahab, Solichin, 2005, Analisis

Kebijakasanaan dari Formulasi ke

Implementasi Kebijakasanaan

negara, Bumi Aksara, Jakarta.

Bryant, Coralie dan Louse G White, 1982,

Managing Development in The

Thirld World, Boulder, Westvies

Press.

Darwin, Muhajir $M$ dan Nurharjadmo, 1995, Kebijakan Publik, Buku Pegangan kuliah, Surakarta :UNS Press,

Fang, Z 2002, E Government in Digital Era

: International Journal of the Computer 10,
Meter, Van DS dan Van Horn, CE, 1978,

The Policy Implementation Process: A Conceptual Framework, administration and Society, New York.

Nurharjadmo, Wahyu Nur dkk, 2013 Dinamika Transisi Kota : suatu Evaluasi atas pelaksanaan satu dekade otonomi daerah di Kabupaten Klaten dan Kota Surakarta, Laporan hasil penelitian

Nurnaningsih dan Rusli, Zaili, 2013, Penguatan kelembagaan daerah, dimuat dalam jurnal Administrasi Pembangunan Universitas Riau, vol 1 no 2 maret 2013.

Ratnasari, Jenivia Dwi dkk, 2010, Pengembangan Kapasitas kelembagaan pada badan Kpegawaian Daerah kabupaten Jombang, dalam Jurnal Administrasi Publik Vol 1 no 3 , Fakultas Ilmu Admnistrasi Universitas Brawijaya, Malang.

Rose, Richard, 2005, The Internet and Governance in Global Context, dalam Journal Public Policy 25, 1-3, Cambridge University Press, United Kingdom.

Razak, Abdul, 2013, Penguatan Kapasitas Dewan perwakilan Daerah dalam Perspektif otonomi Daerah, dalam jurnal ilmu Hukum Universiutas Hasanudin, Amanna Gappa vol 21 no 1 maret 2013.

Riyadi, Suprapto, HR, (2003) "Pengembangan Kapasitas Pemerintah Daerah Menuju Good Governance".Pidato Pengukuhan Guru Besar dalam Ilmu Administrasi Pembangunan padaFakultas Ilmu Administrasi Universitas Brawijaya, Malang 
Sutopo, HB, 2002, Metode Penelitian Kualitatif, UNS Press, Surakarta.

Shuaib, Farid Sufian, 2008, Strengthening Administrative Institution of Islamic Law in Malaysia : An Overview, dalam Jurnal Syariah special edition nomor 16 tahun 2008

Tjokrowinoto, Moelyarto, 2001, Pembangunan. Dilema dan Tantangan, Pustaka pelajar, Yogyakarta.

Wahyono, Bayu, 2011, Optimalisasi Program Desa Informasi mellaui Penguatan Kelembagaan, dalam Jurnal Iptek dan Kom vol 13 nomor 2 desember 2011.

Winarno, Budi, 2002, Teori dan Proses Kebijakan Publik, Yogyakarta, Media Pressindo 